\title{
Sustaining Positive Impact of Covid-19 Movement Control Order (MCO) on Environment through New Norm - Case of Malaysia
}

\author{
Wan Norhayati Wan Ahmad*, Azharudin Ali \\ Tunku Puteri Intan Safinaz School of Accountancy, Universiti Utara Malaysia
}

\begin{abstract}
The Covid-19 pandemic came and brought a big wave of shock to the entire world with several millions of recorded death. Also, its effect on business, economies and human lives is devastating. Hence, many things have changed, including our daily norms. That involves daily activity, education, and economic activities. Even though this pandemic brings fears to the community, there is still a silver lining of this situation. Everywhere around the world were reported to have positive impacts on the environment due to Covid-19 and actions taken in containing it. Literature and reports show that total emissions have decreased due to less usage of fuel, electricity, travelling and the temporary closure of factories. Less air and water pollution are reported everywhere. Despite all these, it was argued that this is going to be a temporary blessing. Things will go back to square when normal activities are restored, and lockdowns are lifted. The question is, could this positive impact be sustained? What can we do to sustain or at least minimise the environmental damage in the future? This paper presents some data on how action to contain Covid-19 such as MCO and lockdown positively impact the environment worldwide especially Malaysia; as well as suggestions on how we could sustain, if not all, some part of these positive impacts through new norms.
\end{abstract}

Keywords: Covid-19, pandemic, lockdown, MCO, environment, climate change, emissions

JEL Classification: Q51, Q53, Q56

Paper Type: Research

*Corresponding author: E-mail: wnwa@uum.edu.my 


\section{INTRODUCTION}

Covid-19 that shocked the world from the end of 2019 has brought a lot of impacts to the nation worldwide. Even though most of the impacts are negative, especially the economic and social impacts, it does somehow bring a ray of light to the environment and climate change. Almost everywhere in the world reported that their countries' emissions have reduced during the lockdown period. The air is cleaner and fresher. The water is less polluted and clearer than ever before. These impacts are the blessing in disguise that the Covid-19 pandemic brought to us word widely. The positive impacts are achieved because we do things differently throughout the movement Control Order (MCO) or the lockdown period. In other words, the new norms were created. With activity restrictions, less fuel and electricity were used. People hardly travel unless there are emergency and urgency to do that. Factories are temporarily closed, so bring down air and water pollutions.

In Malaysia, the study by Silverman and Silverman (2000) found that air pollution and waste management were the main local environmental issues. Their finding also showed that the key causes of air pollution were industrial air emissions and vehicular exhaust. In addition, loss of natural habitat, ozone depletion, climate change and river pollution are other environmental issues faced by Malaysia. The study from Mei, Wai and Ahamad (2016) suggests that Malaysians have a high level of awareness towards environmental issues, especially water pollution. However, a high level of awareness does not mean that they will act accordingly or highly motivated to practice pro-environmental behaviour. The authors also found that the actions taken by Malaysian are influenced mostly by convenience. Even though they know that certain actions are not right but are an easy solution for them, most will still to choose to do it. On the other hand, with the new situation of Covid-19, some of these 'convenience' practice can no longer be practised, at least during the $\mathrm{MCO}$. Thus, perhaps some of these environmental impacts can be reduced.

\subsection{PROBLEM STATEMENT}

Despite all the reported Covid-19 good impacts on the environment; these impacts are argued to be temporary. Questions rise on "Would carbon and pollutant emissions "bounce back" when the pandemic eventually subsides so much that it will be as if this clear-skied interlude never happened?", "Could the changes we see today have a more persistent effect?" (Henriques, 2020), and "How to maintain the environmental benefits once the COVID-19 epidemic wanes?" (Abran, 2020).

Despite our eagerness to end the pandemic so that we can live in our normal life like before, the good impact of the MCO on environments need to be sustained, thus help to achieve the global Sustainable Development Goals (SDG) 2030 outlined by UnitedNationsn in 2015. On the other hand, there is a need to identifies what good impacts were enjoyed before it could be sustained. To date, there are articles on environmental impacts of pandemic Covid-19 especially during the MCO on certain countries like Thailand, Iran, China and Southeast Asia, but there was no specific study done for Malaysia as a whole. Few studies only focus on specific area likes Kuala Lumpur and Klang Valley (Suhaimi, Jalaludin, \& Latif, 2020; Nadzir et al., 2020). Besides, this study provides suggestions and measurements of how the positive impact could be sustained for the long run; which works of literature do not provide. Further, the works of literature related to Covid-19 are still limited, so this study helps to enhance it for future reference. 


\subsection{OBJECTIVES OF THE STUDY}

Based on experiences and the literature, our objectives are to provide awareness on how Covid-19 during MCO has done positively to Malaysia's environment. Further, this paper also provides practical suggestions for policymakers, organisations and society on how to sustain these good impacts in the long run.

\section{LITERATURE REVIEW}

This section provides insight and discussion on available studies related to the impact of Covid -19 on the environment globally. Covid-19 badly affect people globally, yet studies and observations found that there were silver linings of this situation, especially when lockdown or MCO were implemented by the government. In China, the lockdown has reduced emissions by $2,5 \%$, and coal use fell by $40 \%$ at china's largest power plants in early 2020 as compared to the end of 2019. Further, the amount of good quality air was around $11.4 \%$ better compared to the same time last year, and the number of airborne pollutants like $\mathrm{CO}_{2}$, and nitrous oxides has fallen too (Saadat, Rawtani \& Hussain, 2020; Wang \& Su, 2020). The following graphs show the nitrogen dioxide (NO2) pollution level at the main city in China. In general, figure 1 shows a similar pattern, which is the reduction in NO2, especially during the lockdown period of January to end of March 2020.

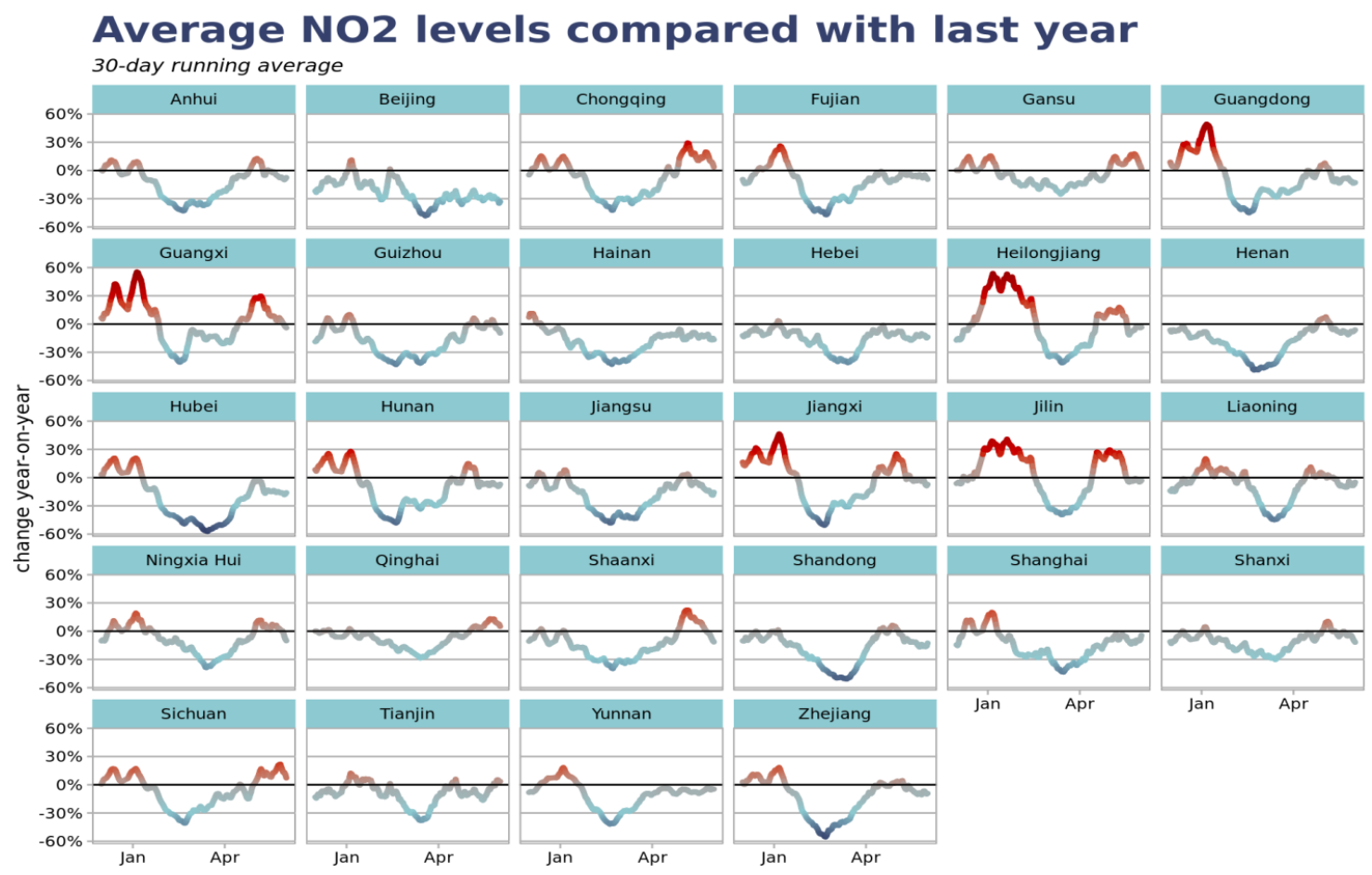

Figure 1. Average NO2 levels compared with last year Source: CREA (2020)

The reduction of the travelling activity during the lockdown period has reduced New York carbon monoxide from transportation by nearly $50 \%$ compared with last year (McGrath, 2020). In Rio de Janeiro, Brazil, the study by Dantas, Siciliano, França, da Silva and Arbilla, (2020) shows that the partial confinement caused the reduction of road traffic and 
economic activity. This has resulted in a decrease in $\mathrm{CO}$ and $\mathrm{NO}_{2}$ levels and, by contrast, to the increase in ozone concentrations.

In February 2019, it was reported that the levels of both air and water pollution in Venice as "worrying". However, the almost two months of lockdown period have left the waters in Venice looking clearer, with the visibility of marine life which hasn't been seen in the city for many years before (Katanich, 2020). In European countries like Portugal and Spain, the two major pollutants (Nitrogen dioxide - NO2 and Particulate Matter - PM10) shows a significant fall, thus bring fresher air during the lockdown period. Figure 2 shows the percentage of the reduction in NO2 and PM10 for Portugal, Spain, Norway and Italy during the lockdown.

\section{Levels of two major pollutants have fallen by over $\mathbf{5 0} \%$ in Portugal as European countries experience cleaner air during lockdown}

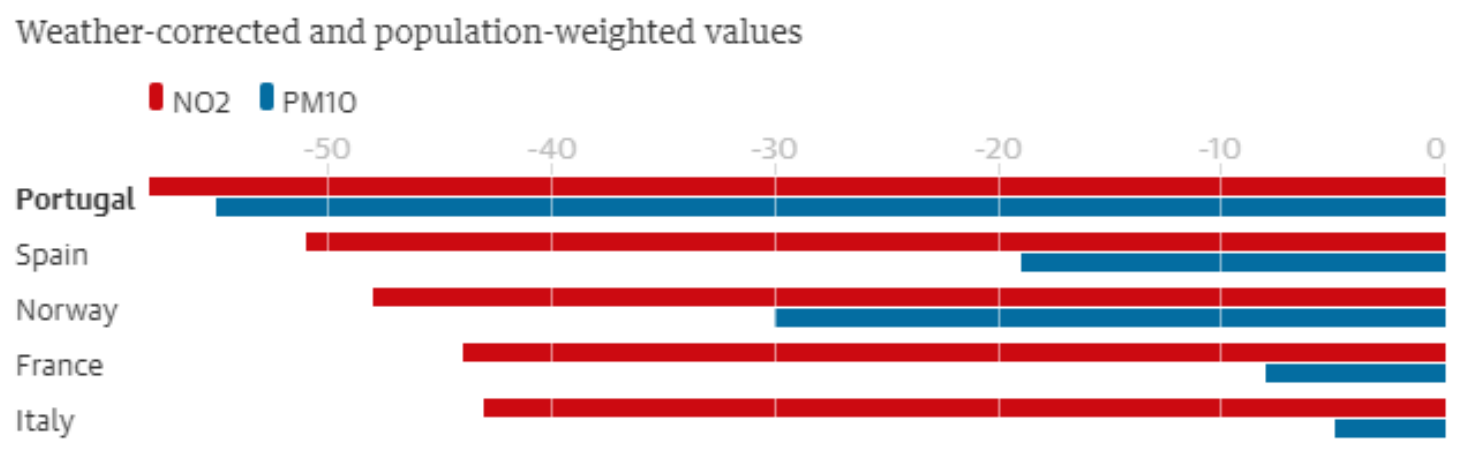

Figure 2. The percentage of the reduction in NO2 and PM10 Source: Watts (2020)

Similar positive impact also found in India. With its vast population, India has always been a hub of pollution, heavy traffics and industries, which has led to a high air quality index (AQI) in all of its major cities. However, the implementation of MCO due to COVID-19 has indicated that the air quality has started to improve and all other environmental parameters such as water quality in rivers have started to give a positive sign of recovering (Lokhandwala \& Gautam, (2020).

\section{METHODOLOGY}

Data for this study were collected through researchers' observations and experience, as well as the review of the literature and published documents in the area of study. The data collections were carried out using an exploratory research approach. The review of the literature and published documents include journals, news, periodicals, report and any other archive data. The findings were analysed and presented based on study objectives; the environmental impact of MCO and the recommendations on how the good impacts could be sustained. 


\section{RESULTS}

\subsection{Malaysia Environmental Impact of Covid-19's MCO}

Malaysia is not left behind in benefiting from Covid-19 lockdown environmentally. There are two main environmental benefits that we want to highlight in this paper; positive impact on beach and river, as well as the positive impact on air quality and climate change through carbon emissions.

\section{a) Cleaner and Clearer Beaches and Rivers}

In Malaysia, $97 \%$ of Malaysia's water supply comes from rivers. Therefore, poor river water quality will severely affect water supply to the communities (Chan, 2012). Further, Chan (2012), suggest that a combination of mismanagement, apathy, low priority on government agendas, lacks funds, poor public involvement, and poor enforcement has severely degraded river water quality in Malaysia especially at rural area. The polluted rivers have caused pollutions, floods and water shortage to the community. However, during MCO, there are tremendous changes that have happened to our polluted rivers all over the country. According to Environment and Water Minister Datuk Tuan Ibrahim Tuan Man, Air Pollutant Index levels dipped by 14 per cent to record a "clean index", while 28 per cent of its 29 automatic water monitoring stations' readings showed a real-time improvement in water quality during MCO. (Babulal, 2020). Among the rivers showing improved water quality are Sungai Linggi, Sungai Muar, Sungai Johor and Sungai Pahang, Sungai Kuantan, Sungai Besut, Sungai Kelantan and Sungai Batang Sadong. Figure 3, Figure 4, Figure 5 and figure 6 represent the comparison of Sungai Melaka and Sungai Pinang before and during MCO.

Cleaner beaches and rivers are due to the restricted human activity, including industry operations. Since tourists cannot spend their times loitering around the beach, it also prevents them from littering these spots of attractions. Our observations on tourist sports especially beach shows that most of the pollutions are mostly caused by tourist behaviour who do not throw their litters inappropriately, as well as from the tourism activities such as boating and jet skiing. 


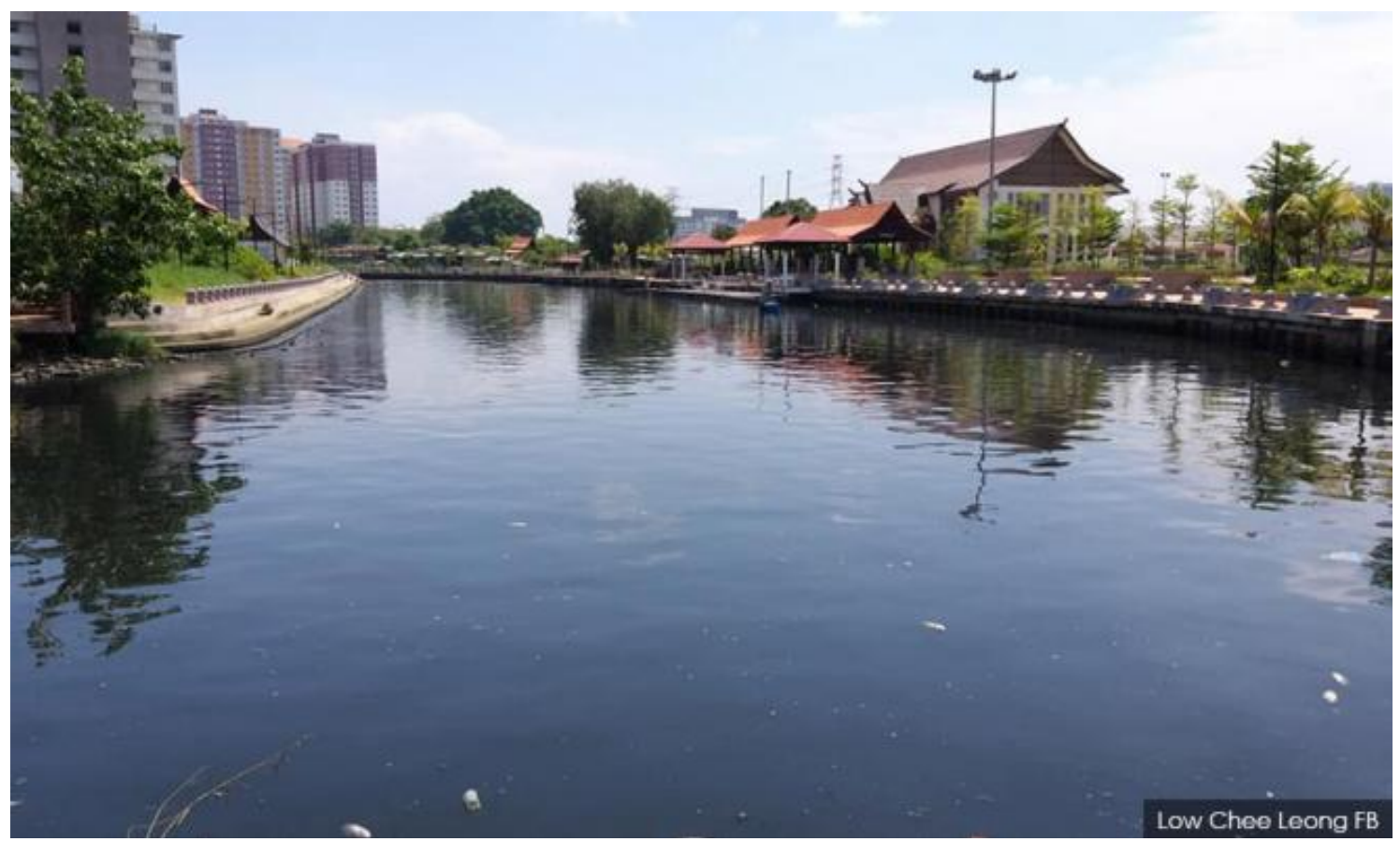

Figure 3. Sungai Melaka before MCO (May 2019)

Source: Low (2019)

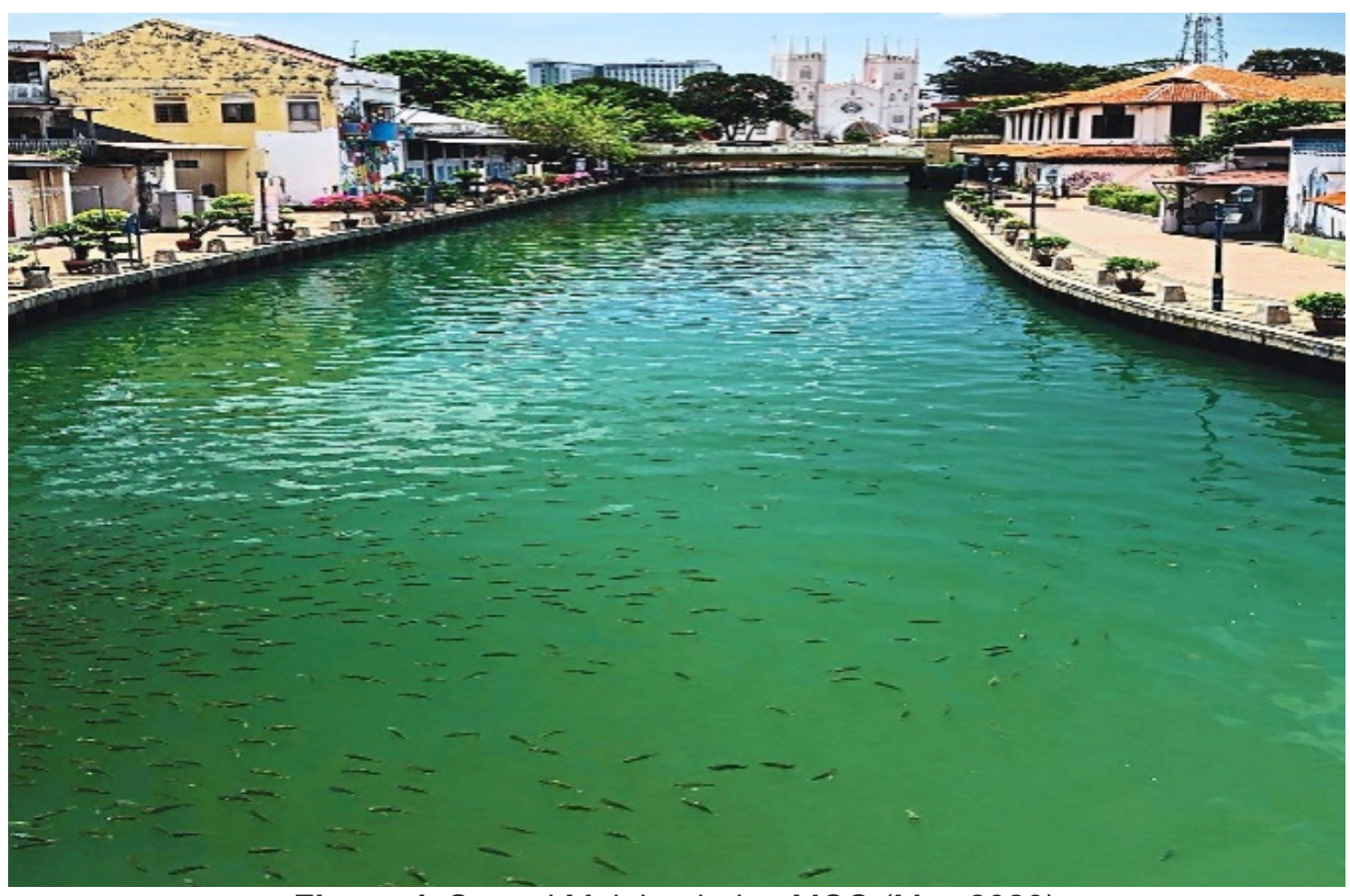

Figure 4. Sungai Melaka during MCO (May 2020)

Source: Fen (2020) 


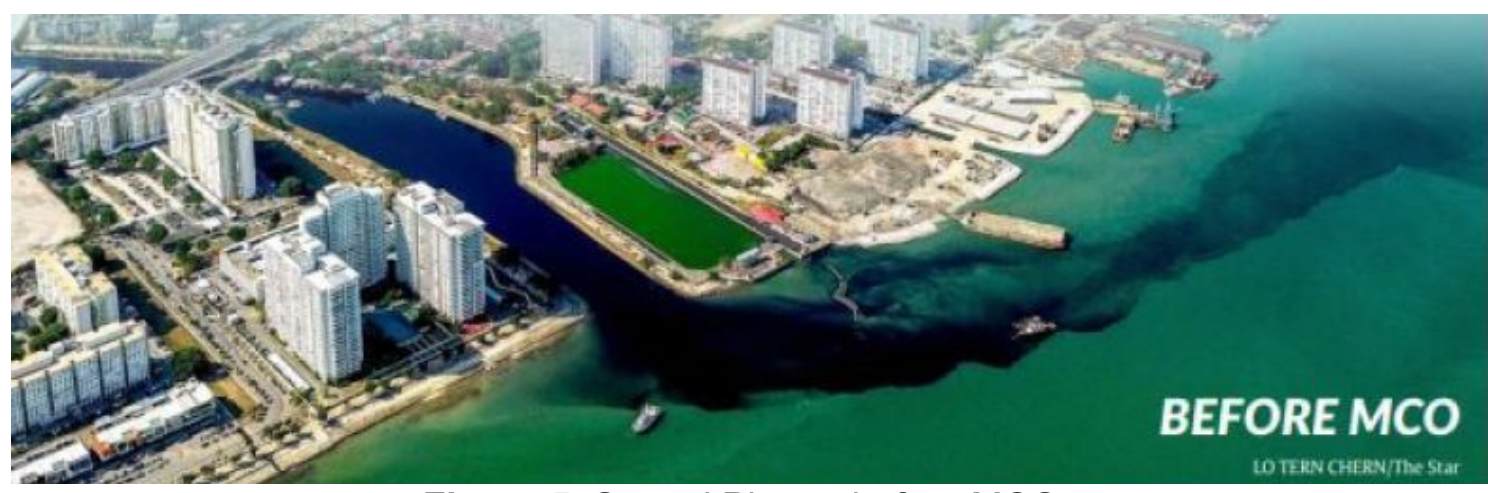

Figure 5. Sungai Pinang before MCO.

Source: Lo (2020)

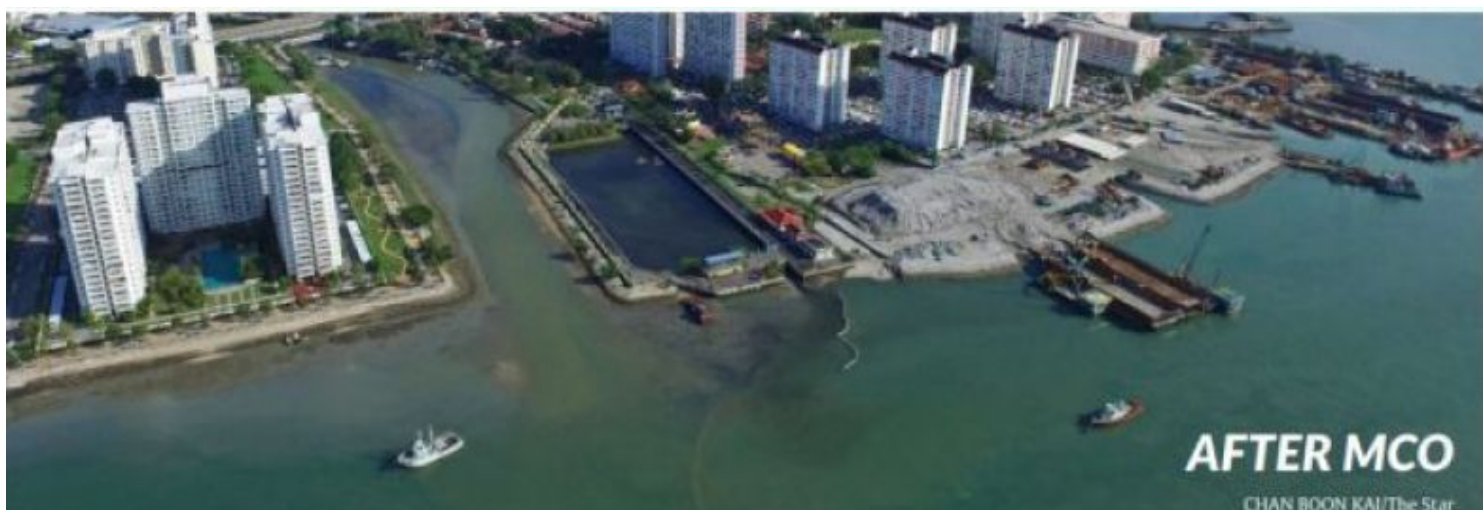

Figure 6. Sungai Pinang after MCO.

Source: Chan (2020)

b) Better Air Quality and Less Carbon Emissions

The main source of Malaysia's GHG Emission is through electricity and productions; as well as transportation, as shown in Figure 7.

\section{Percentage of Emissions by Sector (2017)}

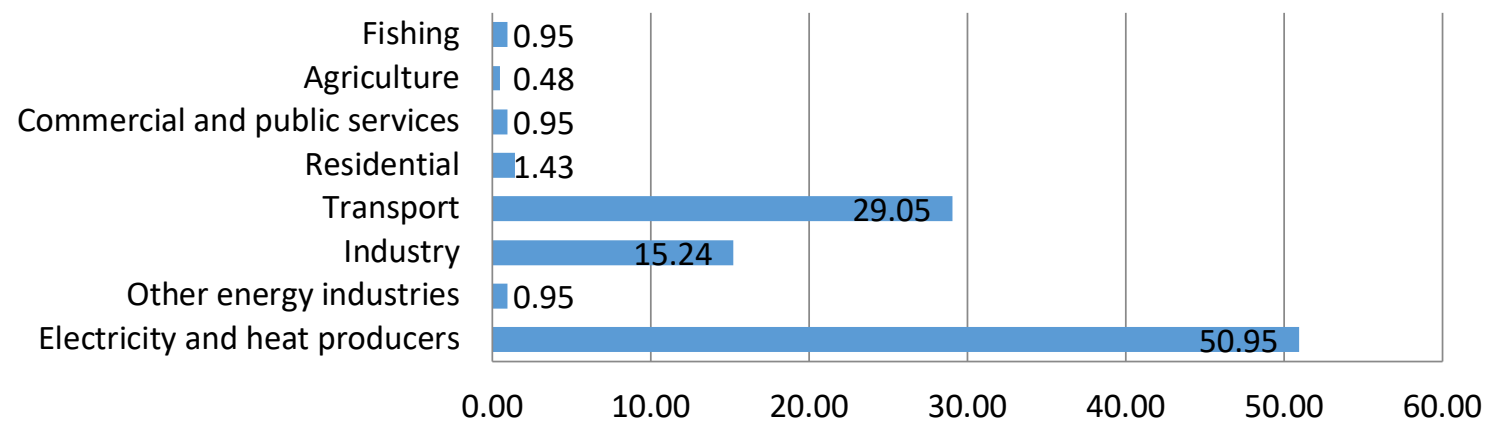

Figure 7. Percentage of Emissions by Sector (2017)

Source: IEA (2020) 
The temporary halt of business and industrial operations, as well as the restricted movement and travelling, has significantly affected the number of emissions released to the atmosphere. As a result, The Minister of Environment and Water reported that at the end of the first phase of $\mathrm{MCO}$, the Air Pollutant Index decreased by 14 per cent. Further, he also reported that Sulphur dioxide (SO2) and particles under 2.5 microns (PM2.5) had gone down by 27 per cent and 29 per cent respectively. Meanwhile, carbon monoxide (CO) and nitrogen dioxide (NO2) levels had dipped by 49 per cent and 70 per cent, respectively. Further, the air pollutant measurement using a reference analyser and AiRBOXSense showed that the levels of the measured pollutants dropped by 20 to $60 \%$ during the MCO days at most locations in Klang Valley (Nadzir et al., 2020).

The reduction in carbon emission not just clear the air that we breathe, but also maximise the amount of sunlight reaching the Earth to radiate the solar panels in photovoltaic (PV) systems. As a result, energy production was increased (Naderipour, Abdul-Malek, Ahmad, Kamyab, Ashokkumar, Ngamcharussrivichai, and Chelliapan (2020).

\subsection{How new norm helps sustain the environmental benefits once the COVID-19 epidemic wanes?}

Practising the new norms. Continue doing what we do during the MCO that help preserve our environment, directly or indirectly. That should be one of the key answers to this question. This is because the achievement that we enjoy today is the result of the new norm practised by society. When we said practising new norms, this suggestion does not include the disclosure of economics and industrial activities, but to improve these two operations by doing it differently and comfortably. The initiatives might look simple, but it might give significant impacts if it becomes a habit or culture to the society and organisations. Below are the things that we should continue to doing to minimise harm to our environment.

\section{a) Reduce Emissions}

Carbon emissions decrease during the $\mathrm{MCO}$ because there were less travelling, so less fuel burning is needed. Social distancing and limit ourselves from going out unnecessarily also contribute to the less carbon been released to the open air. The new norm of work from home would reduce the electricity used in an organisation, thus further reduce emissions. One might argue that when we work from home, we still use electricity, but we strongly believe that the amount used is significantly lower. An organisation can minimise their electricity usage through air-conditioner, lights and other electrical devices such as computers and printers. Working from home reduces employees travelling needs, thus saving fuel consumptions. During MCO, we observe that most of the organisations, businesses, government agencies, and families are making use of technology and social media to get connected. With interstate travel restrictions, meetings are done through online. Suddenly we are exposed to Zoom, Webex, Google Meet, Microsoft Team, Hangouts Meet and many more. Now, we do not have to travel for a meeting, and yet we still can participate in our comfy place. What makes it more comfortable is that you don't have to wear your formal office attire! The same goes for education, where students do not have to commute to school every day and spend most of their time at school, yet they can meet and learnt from their teacher virtually. Of course, awkward at first.

In term of education, however, there are a lot of arguments on virtual teaching and learning. Many argue that virtual education is less effective and minimise social interactions needed by children and students. To overcome this, we would suggest the 
hybrid method where there is combinations of physical meeting and virtual meeting, especially for university students. We believe the hybrid approach does not just reduce in campus travelling and energy usage, but may also resolve some parking problems around academic buildings.

In addition to the above, online shopping is also a booming trend; and a new experience for some. Online shopping also encourages less travelling; thus, less carbon is emitted through transportation.

\section{b) Change of behaviour}

Most of the environmental problems (and other problems) are caused by human behaviour (Abusafieh \& Razem (2017). Thus the cure for that problem is the cause itself. The improved water quality during $\mathrm{MCO}$, as well as the cleaner beaches, is not caused by a new norm practised during MCO, but rather a temporary pause of practising the bad habit. Water pollution in Malaysia is caused by public apathy and illegal factories (Bernama, 2019), that threat beaches and rivers (especially) as an open, free dustbin. Beaches are clean during $\mathrm{MCO}$ because people cannot go there and practice the bad habit of loitering around and do not feel responsible to the planet that they live. Therefore, when the MCO is lifted, and people are free to go out again, it is afraid that the existing problem will come back in a blink of an eye. Rivers are cleaner and clearer because industries and factories operations were halted. Thus those unethical operators cannot dump their waste into the water. What happens when they go back to operation again? Individual people and organisations need to have new practice, a new habit, and the new norm. As suggested by Kollmuss and Agyeman (2002), habit is one of the important factors that shape proenvironmental behaviours. The new norm was not created through MCO but learnt during MCO. After MCO is lifted, we should be a new, better person, those that appreciate nature and understands its importance for us, and stop littering and polluting.

\section{c) Better waste management}

Water quality is improved when human and industrial activities being restricted. This signals that the previously bad quality water is resulted from mismanagement of waste by individual and industry. If people and organisations do not want to change their bad practice and habits, then stricter enforcement should come in. Industries especially, should not sacrifice the environment and community's health for their own profit sake. Policymaker has to make sure that the industry implements proper waste management and no more treating river as their dustbin. The study by Tey, Goh, Kek and Goh (2013) reveals that most of the Malaysian construction companies do not have a proper waste management system in managing construction waste. Most of them are using landfill for disposing waste and only a few of them practising the $3 R$, that is, recycle, reduce, and reuse in managing their waste.

\section{d) Be Innovative}

Sometimes the solution that we need does not yet exist, so innovate it. For example, if our mortar and brick business cannot survive during MCO; then find another way that can still make our business visible. Go online. Go viral. Use social media. Connect with all your contacts and network. Let's the technology do the promotions for you. Change your business model. If you cannot let your customer comes to your shop, go to them. Reach them. Deliver to them. The same thing goes to the environment. Can your organisation practice green management? Can we innovate so that less energy is used in your office? Be ingenious, create the solution; because the future is moving towards creating the 'solution' as a 'business' product. According to Carrión-Flores and Innes (2010), specific 
innovation on environment, or environment innovation environmental innovation is an important driver of reductions in US toxic emissions. Also, they found that tight pollution targets encourage better environmental innovation. Long, Chen, Du, Oh, Han, and Yan (2017) recommend that organisations need to strengthen cleaner production processes to reduce environmental pollution through progressing in environmental innovation. The above recommendations are consistent with the latest study by Rehman, Kraus, Shah, Khanin and Mahto (2020) where they have found that green innovation strategies contribute to better environmental performance.

\section{e) Better enforcement}

How would we know that our organisation has successfully reduced carbon emissions during MCO? Even if it is true, then how much the reduction is? Organisations can make assumptions that with less electricity being used, and fewer travels are made during MCO, they have fewer carbon emissions. Its sound like a logical argument but organisations cannot prove it if they do not have figures to show. Can they show how much is their emissions, before and after the pandemic? In answering this question, an organisation need to have a system that first captures the amount of emissions that convert it into Co2 equivalent units for quantification. Since Malaysia do not make it compulsory for emission reporting, thus emissions measurement is not a priority to most of the Malaysian organisation. To measure is to manage. If organisations do not know how much they pollute the environment, then the management part seems to be unnecessary. They won't see the importance or the necessity of it. Therefore, enforcement is needed, at least with the compulsory measurement of organisations' emissions. From that, later development would be the enforcement on the disclosure.

Other than emissions, enforcement on waste management is also vital as most of the pollution is caused by industrial waste as well as household waste. As for tourism spots, the aqua-tourism operators should be more responsive to the environment and work together amongst them so that the environment, especially around their business area is taken care of. For example, all hoteliers around Beach A would collectively pay a certain amount to waste management operator to make sure that the beach where their business is, is always clean. This would also attract more tourists, as well as protecting the country's image.

\section{CONCLUSIONS}

There is no doubt that Covid-19 pandemic brings chaos in our life as it threatens us with a deadly disease and changes the way we live. In breaking the Covid-19 chain, a lot has been done by the government to contain the pandemic, including MCO. Economically, many have been badly impacted by MCO while others finding new economic opportunity during this period. In all the tests that God give us, there must be at least a thin silver lining that comes with it. The same thing goes with this Covid-19. The movement restriction has caused a tremendous improvement to the environment when we can inhale fresher air, drink cleaner water, enjoy a fresher environment around us. However, this sudden bless may go away as quickly as it comes if no measures are taken to sustain at least some of it. We hope that the lesson we have learnt during MCO could at least change our bad habit to become a better one for better Malaysia, and a better world in the future. 
Sustaining Positive Impact of Covid-19 Movement Control Order (MCO) on Environment through New Norm - Case of Malaysia

\section{REFERENCES}

Abran, S. (2020). Coronavirus: world's response has slashed $\mathrm{CO}_{2}$ emissions - here's how to keep them down. The Conversation.

Abusafieh, S., \& Razem, M. (2017). Human Behavior and Environmental Sustainability: promoting a proenvironmental behaviour by harnessing the social, psychological and physical influences of the built environment. In E3S Web of Conferences (Vol. 23, p. 02003). EDP Sciences.

Babulal, V. (2020, April 18). New Strait Times. Retrieved at https://www.nst.com.my/news/nation/2020/04/585488/air-and-water-quality-improve-duringmco?fbclid=IwAR0UfW7f2iRDN85rqGqlln_hNEHooBV8GhSnIQYwISHI_cQW7HSJwXYxQWM

Carrión-Flores, C. E., \& Innes, R. (2010). Environmental innovation and environmental performance. Journal of Environmental Economics and Management, 59(1), 27-42.

Chan, B. K. (2020). [Sungai Pinang after MCO] [Photograph] The Strait Times. https://www.straitstimes.com/asia/se-asia/once-pitch-black-penang-river-now-jade-green-thanks-tocoronavirus-movement-curbs

Chan, N. W. (2012). Managing urban rivers and water quality in Malaysia for sustainable water resources. International Journal of Water Resources Development, 28(2), 343-354.

Dantas, G., Siciliano, B., França, B. B., da Silva, C. M., \& Arbilla, G. (2020). The impact of COVID-19 partial lockdown on the air quality of the city of Rio de Janeiro, Brazil. Science of The Total Environment, 729, 139085.

Fen, C. J. (2020). [Sungai Melaka during MCO] [Photograph] The Star. https://www.thestar.com.my/news/nation/2020/05/01/photographer-clears-the-air-over-sg-melakareports

Henriques, M. (2020). Will Covid-19 have a lasting impact on the environment. BBC News. Retrieved at https://www.joliet86.org/assets/1/6/Will_Covid19_have_a_lasting_impact_on_the_environment_BBC Future.pdf

IEA ${ }^{-}(2020)$. Data and Statistic. Available at https://www.iea.org/data-andstatistics?country=MALAYSIA\&fuel=CO2\%20emissions\&indicator=CO2\%20emissions $\% 20$ by $\% 20$ secto $r$

Katanich, D. (May 07, 2020). Euro News. Retrieved at https://www.euronews.com/living/2020/05/07/what-isvenice-s-real-ecological-profit-from-the-lockdown

Lo, T. C. (2020). [Sungai Pinang before MCO] [Photograph] The Strait Times. https://www.straitstimes.com/asia/se-asia/once-pitch-black-penang-river-now-jade-green-thanks-tocoronavirus-movement-curbs

Lokhandwala, S., \& Gautam, P. (2020). Indirect impact of COVID-19 on the environment: A brief study in the Indian context. Environmental Research, 188, 109807.

Long, X., Chen, Y., Du, J., Oh, K., Han, I., \& Yan, J. (2017). The effect of environmental innovation behaviour on the economic and environmental performance of 182 Chinese firms. Journal of cleaner production, $166,1274-1282$.

Low, C. L. (2019). [Sungai Melaka before MCO] [Photograph] Malaysia Kini. https://www.malaysiakini.com/news/476811

Kollmuss, A., \& Agyeman, J. (2002). Mind the gap: why do people act environmentally and what are the barriers to pro-environmental behaviour? Environmental education research, 8(3), 239-260.

McGrath, M (March 19, 2020). BBC News. Coronavirus: Air pollution and CO2 fall rapidly as the virus spreads Retrieve at https://www.bbc.com/news/science-environment-51944780

Mei, N. S., Wai, C. W., \& Ahamad, R. (2016). Environmental awareness and behaviour index for Malaysia. Procedia-Social and Behavioral Sciences, 222(7), 668-675.

Muhammad, S., Long, X., \& Salman, M. (2020). COVID-19 pandemic and environmental pollution: A blessing in disguise? Science of The Total Environment, 138820.

Naderipour, A., Abdul-Malek, Z., Ahmad, N. A., Kamyab, H., Ashokkumar, V., Ngamcharussrivichai, C., \& Chelliapan, S. (2020). Effect of COVID-19 virus on reducing GHG emission and increasing energy generated by renewable energy sources: A brief study in the Malaysian context. Environmental technology \& innovation, 20, 101151.

Nadzir, M. S. M., Ooi, M. C. G., Alhasa, K. M., Bakar, M. A. A., Mohtar, A. A. A., Nor, M. F. F. M., ... \& Anuar, J. (2020). The impact of movement control order (MCO) during pandemic COVID-19 on local air quality in an urban area of Klang Valley, Malaysia. Aerosol and Air Quality Research, 20(6), 1237-1248.

Rehman, S. U., Kraus, S., Shah, S. A., Khanin, D., \& Mahto, R. V. (2020). Analysing the relationship between green innovation and environmental performance in large manufacturing firms. Technological Forecasting and Social Change, 120481.

Saadat, S., Rawtani, D., \& Hussain, C. M. (2020). Environmental perspective of COVID-19. Science of The Total Environment, 138870. 
Silverman, G. S., \& Silverman, M. K. (2000). Perceptions of environmental problems by Malaysian Professionals. Environmental Practice, 2(4), 299-310.

Suhaimi, N. F., Jalaludin, J., \& Latif, M. T. (2020). Demystifying a possible relationship between COVID-19, air quality and meteorological factors: evidence from Kuala Lumpur, Malaysia. Aerosol and Air Quality Research, 20(7), 1520-1529.

Tey, J. S., Goh, K. C., Kek, S. L., \& Goh, H. H. (2013). Current practice of waste management system in Malaysia: Towards sustainable waste management.

Wang, Q., \& Su, M. (2020). A preliminary assessment of the impact of COVID-19 on the environment-A case study of China. Science of the Total Environment, 138915.

Zambrano-Monserrate, M. A., Ruano, M. A., \& Sanchez-Alcalde, L. (2020). Indirect effects of COVID-19 on the environment. Science of The Total Environment, 138813. 